
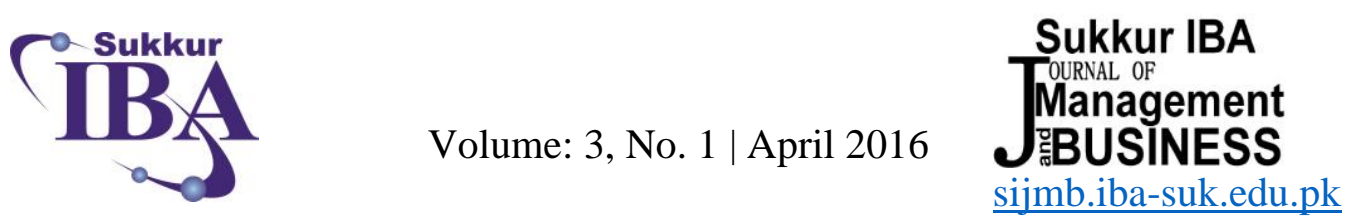

\title{
The Impact of Organizational Culture Types on the Job Satisfaction of Employees
}

\author{
Maham Fatima $^{1 *}$ \\ MS Scholar at Quaid-i-Azam School of Management Sciences \\ Quaid-i-Azam University Islamabad
}

\begin{abstract}
The study focused on investigating the impact of organizational culture types on the job satisfaction of employees. The study was based on four cultural types named as clan, adhocracy, market, and hierarchy culture. The empirical investigation was conducted by data collection from 11 organizations of Rawalpindi and Islamabad with the help of questionnaire based on five points Likert scale. The famous organizational culture model adopted from research of S. K. Cameron, \& Freeman, J. S. (1991) which incorporated clan, adhocracy, market and hierarchy cultures were utilized to test hypotheses against job satisfaction. The study was based on collection of data from entrepreneurial organizations and it was interesting to note that all the four type of cultures were prevailing in the same nature of the organizations. The study was conducted in order to cater with the discrepancies found in the literature. The Asian cultural studies depict contradictory phenomena as compared to the Western studies and this study added to the literature by showing that being Asian country the results match with the studies conducted in Western settings. The study suggests that culture types strongly impact the job satisfaction of employees. Employees working under clan and adhocracy culture were satisfied with their jobs. While those working under hierarchy and market cultures were dissatisfied with their jobs. The findings of the study are not just significant for academic purposes but are also critical for managers in determining the employee job satisfaction.
\end{abstract}

Keywords: Organizational culture, Job satisfaction, Clan culture, Market culture, Hierarchy culture, Adhocracy culture.

\section{Introduction}

A term of anthropology culture refers to the beliefs, norms, principles and values that exist in a society. Culture is one of the dominant and leading factor which influences the beliefs and values of individuals. As organizations form part of the society the culture is one of the significant indicators in organizations too. As culture also prevails https://doi.org/10.30537/sijmb.v3i1.135

${ }^{1}$ maham.fatyma@gmail.com

* Corresponding Author

SIJMB | E-ISSN: 2410-1885; P-ISSN: 2313-1217 @ 201613 Sukkur Institute of Business Administration - All rights reserved 
in an organization where employees share values and beliefs these factors influence them at their job Huey Yiing and Zaman Bin Ahmad (2009); J. JOHNSON and McIntye (1998); Lund (2003); Schiuma et al. (2012). The area of organizational culture can be traced back to the last part of the Hawthorne studies but it was not until late 1970's when researchers started to focus keenly on the area of organizational culture. With the start of 1980's it was the time period when the term "organizational culture" became vastly popular. Culture that prevails in organization is one of the basic indicators or factor which needs to be understood in order to study and understand an organization. The culture of an organization is actually the particular behavior and attitude of a group of people which is affected by certain norms of the organization. The reason behind the popularity was the awareness of managers with the fact that culture plays a significant role in determining the job satisfaction of the employees. The popularity of organizational culture increased the interest of researchers and scholars in this area and they started to explore it in their studies. Hofstede (1984), was the researcher who widely explored the area of culture. Later on Deal and Kennedy (1982), worked on organizational culture. They defined it as the manner by which things are done in an organization. Schein (1990), added to the subject with his research which focused on internal and external integration of resources which helps an organization to flourish and if the culture is positive it helps organizations to gain competitive advantage too. S. K. Cameron, \& Freeman, J. S. (1991), worked on the culture currently prevail within an organization to the preferred culture that employees want in an organization. This study is a very helpful tool for determining the impact of culture on employees.

As numerous studies suggest organizational culture as one of the most important area Adler and Jelinek (1986); Boxx, Odom, and Dunn (1991); Chatman (1989); Chatman, Polzer, Barsade, and Neale (1998); Deshpande and Parasuraman (1986) and management recognize the relevance of organizational culture with job related variables such as job performance, job satisfaction and job commitment etc. Hofstede (1984); (Eric MacIntosh \& Doherty (2005), (2007); (E MacIntosh \& Doherty, 2008); (O'Reilly, Chatman, \& Caldwell, 1991); (Quinn, 1988). Culture is an area of interest for the managers because of the fact that it forms the behavior of employees towards their organization and towards their job. Rosenfield (1998), worked on two schools of thoughts regarding culture. The two schools distinguished, includes applicable school of thought and analytical school of thought. The former focused on the history of a culture of an organization and the impact of that culture on the behavior of employees. While the later focused on culture in terms of leading and gaining competitive advantage. The former focuses more on the job satisfaction of employees in relation to culture of an organization. As the area of organizational culture is relatively new there have been a few studies which explored the relationship of organizational culture with job satisfaction. Buono, Bowditch, and Lewis (1985), explored the impact of merger on employee job satisfaction as the culture of organization changes with the strategic decision of mergers. Deshpande, Farley, and Webster Jr (1993), studied job satisfaction of employees by using culture type framework in order to know job satisfaction of employees in USA. Nystrom (1993) studied the job satisfaction variable in relation to

SIJMB | P-ISSN: 2313-1217 E-ISSN: 2410-1885 @ 201614 Sukkur Institute of Business Administration V.3, No.1 | Apr 16 
the culture of health care and medical organizations. Lund (2003) studied the marketing profession in cross sectional firm and explored the level of job satisfaction with respect to the prevailing culture in their organizations. These studies develop the basis for studying organizational culture of firm with their respective culture type in order to know job satisfaction of employees.

It is also significant to note that there various studies have incorporated various organizational culture models Agho, Mueller, and Price (1993); Boxx et al. (1991); Hofstede, Neuijen, Ohayv, and Sanders (1990) and very few focused on the framework developed by S. K. Cameron, \& Freeman, J. S. (1991); Lund (2003). Also, the domain of organizational culture is separate from that of corporate culture and in past researchers have considered corporate culture as organizational culture (Deal \& Kennedy, 1982); (Huang \& Wu, 2000). This study aimed at identifying the type of cultures prevailing in entrepreneurial organizations which are same in nature but the significantly differ in terms of leadership, the strategic directions, management of employees, the measurement of success criteria and dominant characteristics.

A significance of this study is in terms of the fact that past researches either took organizational culture as one single variable or explored a particular type of culture. Also few models were utilized and this model was not vastly explored. Another of the interesting fact is that the cultural studies in Asian context depict different results and discrepancies are seen in terms of the linkage of the variables. This study addresses those lacked areas by studying various cultural types with a model that is not vastly explored. The research will provide answer to the problem statement that "organizational culture types impact the job satisfaction of employees in entrepreneurial organizations"?

\section{Literature Review}

\subsection{Organizational Culture}

Organizational culture is a topic of interest in academics; many researchers have done immense work on culture Quinn and McGrath (1985); Quinn and Rohrbaugh (1983); Schein (1984); Schneider and Snyder (1975); Wilkins (1983) as it affects many dimensions including the satisfaction of employee at work Lund (2003); Eric MacIntosh and Doherty (2007) defined organizational culture as forces which influence the coordination of members of an organization. These forces include the values, principles, beliefs and the basic rules followed by an organization which ultimately affects the behavior of the employees of that organization. According to Daft (2001), organizational culture comprise of the key values and the basic assumptions including the principles and norms which are accepted and jointly shared by the members of the organization.

The variable of organizational culture has been studied vastly by many researchers with some studies having focus on the visible artifacts of culture while other focused mainly

SIJMB | P-ISSN: 2313-1217 E-ISSN: 2410-1885 @ 201615 Sukkur Institute of Business Administration V.3, No.1 | Apr 16 
on the deep rooted factors. The studies that investigated the visible parts of the culture of an organization included factors such as slogans, ceremonies, signs and symbols while other studies that deeply explored the cultural factors focused on values and norms (Davis, 1990). Researchers of organizational culture have also proposed different forms and types of cultures. K. Cameron and Quinn (1999), identified that the organizational cultures are divided into four kinds based on some competing values which generates an organizational profile for an organization. Visible and invisible factors combine together to formulate the cultural profile for an organization. The location, architecture and dress code are some of the example of visible culture while invisible culture includes the way to achieve and strive for a target; the philosophies followed by the management and the attitudes and believes. K. Cameron and Quinn (1999), in their research vastly explored the culture type by developing an authentic scale to analyze the type of these cultures. Clan culture is the culture which invites friendliness, is like a home and employees regard it as a family. Employees are loyal to the organization; the figure head treats every employee with love and care. Employees are more committed to their work and the organization focus on the development of the employees with the long term orientation of employees as well as the benefits of the organization. Adhocracy culture is one where the focus of organization is on innovation and risk taking. Organization of such cultures achieves their targets with the help of differentiation edge brought by innovation. The figure head in such cultures are the transformational leaders who keep on bringing changes and improvements in the organization. The market focused cultured organizations emphasis on the short term outputs. The employees working in such type of organizations are competent and proficient. Organizations with market culture focus on gaining most of the market share by using competitive pricings. Hierarchy culture focuses on a very organized and formalized working environment. Rules and procedures are strictly followed with a focus on achieving goals with incurring very low cost. According to Daft (2001), the cultures existing in organizations are adaptability, clan, bureaucratic and achievement culture. S. K. Cameron, \& Freeman, J. S. (1991), identified the culture types as clan, adhocracy, market and hierarchy and organizations are generally a mixture of these cultures with one of the culture as the dominant one. Deal and Kennedy (1982), in their research said that culture is a critical factor for the success of an organization. They worked on four dimensions of cultures which included symbolic attributes, people working in an organization who follow certain attributes, the informal communication network and the values which forms the center for the organization. S. K. Cameron, \& Freeman, J. S. (1991), used four quadrants to represent the culture of an organization which is appropriate for an organization to follow in a particular situation. These quadrants included the values and beliefs in relation to the culture of an organization.

SIJMB | P-ISSN: 2313-1217 E-ISSN: 2410-1885 @ 201616 Sukkur Institute of Business Administration V.3, No.1 | Apr 16 
Figure 1: Culture Types

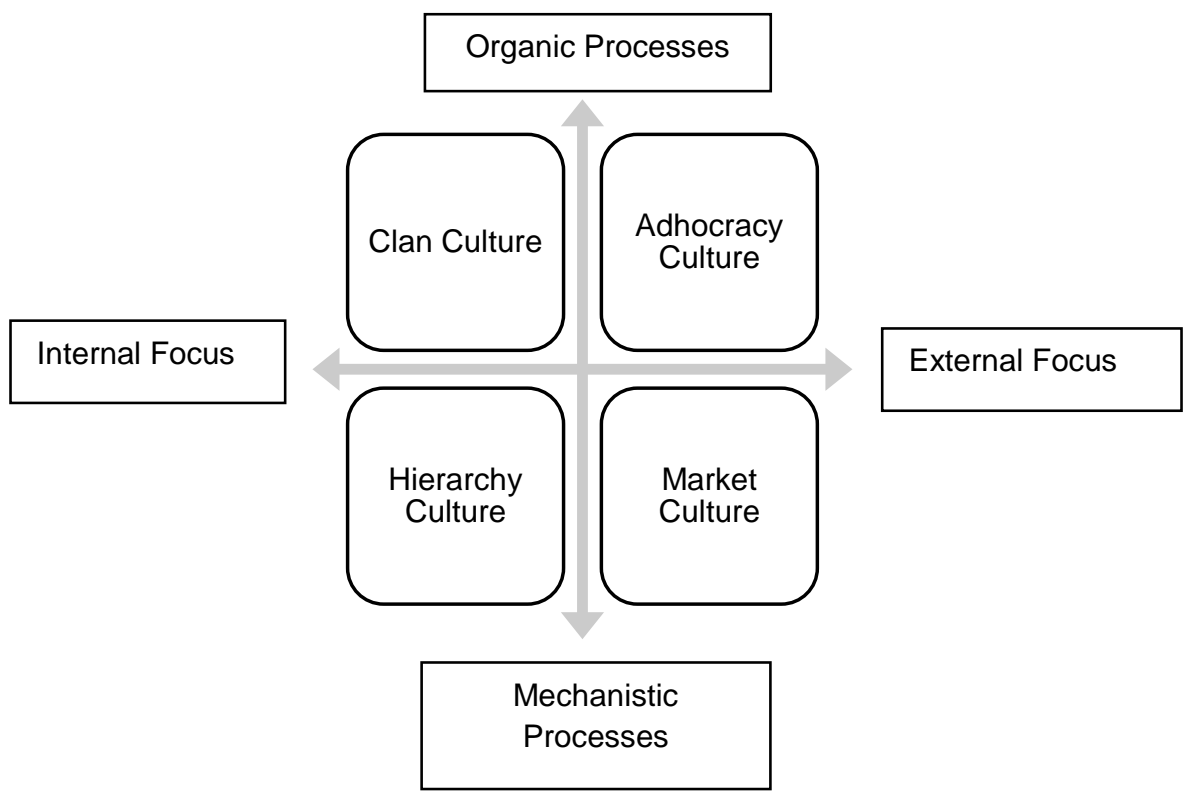

Source: Adopted from Cameron and Quinn (1999)

Lund (2003), in his study found out that the most dominant culture in US firms is market culture. Wallach (1983) argues that organizations are not made up of a single culture instead they are formed with the help of bureaucracy, supportiveness and innovation. Organizations vary in degree to which each of the form combine to make a culture in an organization. A reflection can be seen in working of the organizations in the way they are managed, structured and developed (Hofstede, 1984). The working environment of organizations can be divided into eastern and western cultures which have significant impact on the overall culture prevailing in an organization. Further explaining these cultures the ones with eastern values promote collectivism, support, have a bureaucratic control, centralized decision making with no signs of empowerment and a high power distance. On the contrary organizations following the western views supports individualism, have a flatter structure than the taller one which means they are not bureaucratic, low power disparity is there, employees play their part in decision making and employees get more opportunities (Chen, 2002). Organizational culture impacts the goal setting of employees in professional world as well as in their personal life. Organizational culture influence the way employees think, act, perceive things and accomplish the goals (Hansen \& Wernerfelt, 1989).

\subsection{Job Satisfaction}

According to Locke (1969), job satisfaction is the satisfying and confident state of employees which basically is the result of job evaluation on basis of certain criteria. Brooke, Russell, and Price (1988) defined job satisfaction as the satisfaction of needs

SIJMB | P-ISSN: 2313-1217 E-ISSN: 2410-1885 @ 201617 Sukkur Institute of Business Administration V.3, No.1 | Apr 16 
and wants of employees which are shown by the attitude and behavior of an employee towards the job. Job satisfaction in relation to different cultures and their affects have been discussed and examined by different researchers. Kangas, Kee, and McKeeWaddle (1999) defined job satisfaction as employee's feeling about his work and job along with the aspect which influence these feelings including his relations with supervisors, satisfaction with the pay and benefits, terms with his colleagues and opportunities to excel at current job. According to Chan, Shaffer, and Snape (2004), job satisfaction includes feelings of an employee at his job along with the activities he has to perform to responsibilities he has in a particular environment. Agho et al. (1993), explained that job satisfaction depends on the norms and the institutional values of an organization. Locke (1970), evaluated that the level of job satisfaction have a direct relation with the structure of an organization. Flexible structures increase the job satisfaction of employees while inflexibility decreases the level of job satisfaction. Robinson, Robinson, Porporino, and Simourd (1996) in their study explained that formalization impacts the job satisfaction of employees. It basically is the method by which employees are given a task to perform. It totally depends on the organization; some organizations give their employees the flexibility to perform the task others do not, which directly have an impact on the job satisfaction of employees. Spector (1997) suggests that there are certain job oriented factors which affect the job satisfaction level. Environmental factors play a significant role in determining the level of job satisfaction. These factors include wage which helps an employee to fill his basic and social needs. Excelling opportunities which helps an employee to develop himself and which is necessary for the psychological development as well. Relationship and affiliation with one's supervisor and peers is also an important factor which helps to determine the job satisfaction of an employee. Internal conditions and communication also play a significant role for determining job satisfaction as it includes the perceived value about an organization by its employees along with the understanding of employees with the goals of the organization.

\subsection{Organizational Culture and Job Satisfaction}

Flynn, Chatman, and Spataro (2001) identified in their research that organizational culture directly affects the individual behavior as well as the progress and performance of the organization, the individual behavior turns in favor of the organization if employees are more comfortable in the values adopted by an organization. J. JOHNSON and McIntye (1998) identified that there exists a direct relationship of organizational culture and job satisfaction. Culture shows an immense influence on the job satisfaction of employees' working in an organization with specific values and beliefs. Martin (1992) in his study proposed three dimensions of organizational culture as integration, fragmentation and differentiation which ultimately form the values and beliefs for an organization. Huey Yiing and Zaman Bin Ahmad (2009) found in their study that there is a positive correlation between organizational culture and job satisfaction. Lund (2003) identified in his research the relationship between organizational culture and job satisfaction. He identified that clan culture which is most flexible has a positive relationship with the job satisfaction. Adhocracy culture which

SIJMB | P-ISSN: 2313-1217 E-ISSN: 2410-1885 @ 201618 Sukkur Institute of Business Administration V.3, No.1 | Apr 16 
has a focus on innovation is also positively related with job satisfaction. On the other hand market culture with a focus on goal completion and hierarchy culture with a stressful environment is negatively related to the job satisfaction of employees. McKinnon, Harrison, Chow, and Wu (2003) concluded in their research that employees are more satisfied with their job in organizations that opt for innovation and continuous improvements. Odom, Boxx et al. (1991) in their research worked on the impact of organizational culture on job satisfaction with the findings that bureaucratic culture has an impact on job satisfaction of employees. According to Schein (1996), employees working under bureaucratic culture, where employees do not have a friendly environment are least satisfied at work. The culture where organizations were having a supportive cultural environment leads to a higher job satisfaction of employees. Schiuma et al. (2012) found out that there is a negative impact of bureaucratic organizational culture on job satisfaction of employees. Innovative and supportive culture on the other hand had a positive impact on the job satisfaction of employees. Lund (2003) concluded in his research that marketing professional of cross-sectional firms of clan and adhocracy culture are more satisfied with their job than the marketing professionals of market and hierarchy culture. Koberg and Chusmir (1987) identified in their research that bureaucratic, innovative and supportive culture is positively related to the job satisfaction of employees. In an interesting study by Lok and Crawford (1999) it was identified that bureaucratic is the most dominant culture in organizations of China and employees working under such culture are highly satisfied with their jobs. Williams, Manwell, Konrad, and Linzer (2007) conducted a research with a focus on four types of culture on job satisfaction. The culture types included were human resource, entrepreneurial, bureaucratic and rational culture. The results indicated that the most dominant culture is human resource and satisfaction level of employees is also higher in this culture than any other.

\section{Research Framework}

\section{Figure 2: Theoretical Framew ork}

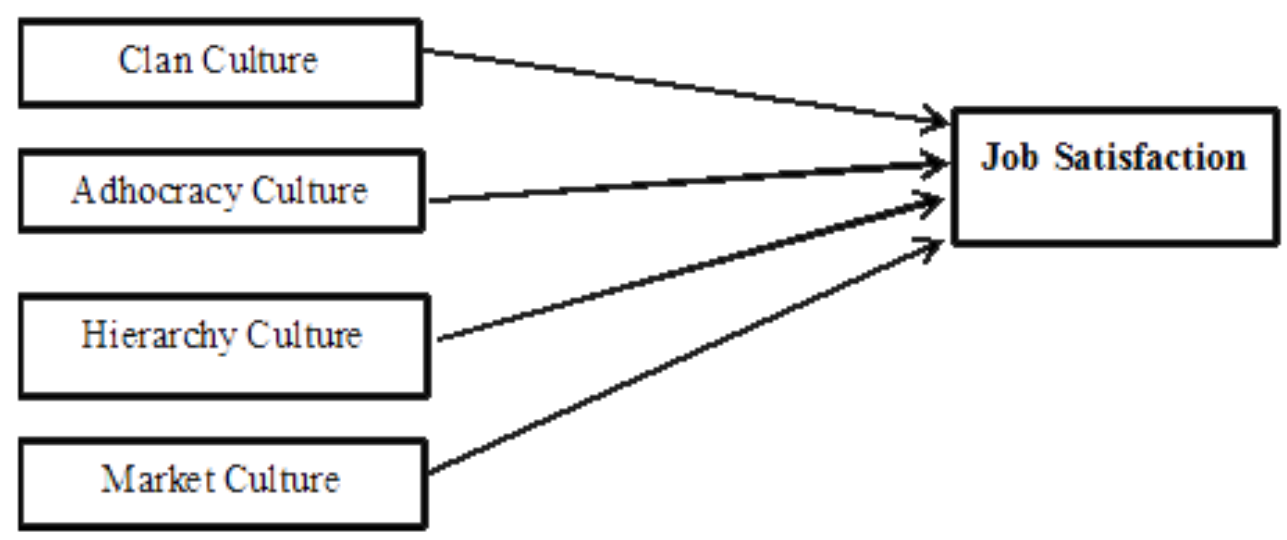

SIJMB | P-ISSN: 2313-1217 E-ISSN: 2410-1885 @ 201619 Sukkur Institute of Business Administration V.3, No.1 | Apr 16 


\subsection{Research Hypotheses}

H1: Employees working under clan culture are satisfied with their jobs.

H2: Employees who work under adhocracy culture are satisfied with their jobs.

H3: Employees working under the hierarchy culture are not satisfied with their jobs.

H4: Employees who work under the market culture are not satisfied with their jobs.

\section{Methodology}

\subsection{Research Instrument}

A self-administrated questionnaire was used as a medium to measure organizational culture and job satisfaction. The scale measuring organizational culture was originally developed by S. K. Cameron, \& Freeman, J. S. (1991) which was ordinal in nature and later on researchers modified it to use for their studies (Shurbagi, 2012). The modified version of the scale was adopted for this study. The modified scale is based on 5 point Likert scale ranging from strongly disagree (1) to strongly agree (5). The variable of organizational culture is divided up into six key dimensions which are named as dominant characteristics, leadership of the organization, employee management, the glue which hold the organization together, the strategic emphasis of the organization and the success criteria. A total of 24 items were used to assess the four types of culture. The four dominating cultures clan, adhocracy, hierarchy and market were measured with the help of this scale.

In order to measure job satisfaction the scale was adopted from Lund (2003) which was developed and utilized for the research by Wright and Cropanzano (1998) to measure the level of employees' satisfaction at work. The scale contains a total of five items that captures the satisfaction of employees with their work, colleagues, supervisors, wages and the excelling opportunities. The scale is based on 5 points Likert scale ranging from strongly disagree (1) to strongly agree (5). The detail of instruments used in this study is presented in Appendix (A).

\subsection{Sample and Data Collection}

The research aimed to determine the job satisfaction of employees of entrepreneurial organizations in Islamabad and Rawalpindi. The data was collected with the help of self-administrated questionnaire which targeted employees of various organizations of Islamabad and Rawalpindi. The total number of questionnaires were distributed to different organization included 200 and a total number of 120 questionnaires were returned from 11 organizations out of the 25 organizations. Non-probability sampling was used to obtain data from respondents; convenient sampling was source of collection of data from the targeted population of Islamabad and Rawalpindi. Of the total respondents $16 \%$ were female respondents while $84 \%$ of the respondents were male. The age of the respondents were between 21-50 years and the years of association with their current organization ranged from less than a year to a range between 6-10 years.

SIJMB | P-ISSN: 2313-1217 E-ISSN: 2410-1885 @ 201620 Sukkur Institute of Business Administration V.3, No.1 | Apr 16 


\subsection{Data Analysis}

The statistical package for social sciences (SPSS 13) was used for analysis of the data. The coding of the variables was done with proper attention. First the mean scores of all the cultures, clan, adhocracy, hierarchy and market were calculated separately. Job satisfaction scores were also calculated by computing the mean scores of the variable. Reliability analysis was performed and Cronbach's alpha was calculated in order to determine the reliability of the data. Item to item and overall data reliability was tested. To test the hypotheses of this study multiple regression analysis was performed. Correlation analysis was also the part of the study which helped in determination of the strength of the relationships of variables. The results are presented with the help of tables for better representation and understanding.

\section{Results and Findings}

5.1. Reliability Analysis

In order to check whether data is reliable or not reliability analysis was performed and the value of Cronbach's alpha helped in determination of data reliability. The itemitem reliability was analyzed and the results are presented in Table 1 which indicate that the data is highly reliable. The data shows reliability of clan culture as .710, adhocracy culture as .812 , market culture as .827 , hierarchy culture as .713 and job satisfaction as .840 . This indicates that the data is reliable as it is greater than 0.7 for all the variables.

Table 1: Item-Item Reliability

\begin{tabular}{lll}
\hline \multicolumn{1}{c}{ Variables } & Number of Items & Cronbach's Alpha \\
\hline Clan Culture & 4 & .710 \\
Adhocracy Culture & 4 & .812 \\
Market Culture & 4 & .827 \\
Hierarchy Culture & 4 & .713 \\
Job Satisfaction & 5 & .840 \\
\hline
\end{tabular}

\subsection{Correlation Analysis}

Table 2: Correlation Analysis

\begin{tabular}{|c|c|c|c|c|c|}
\hline & $\begin{array}{l}\text { Job } \\
\text { Satisfaction }\end{array}$ & $\begin{array}{l}\text { Clan } \\
\text { Culture }\end{array}$ & $\begin{array}{l}\text { Adhocracy } \\
\text { Culture }\end{array}$ & $\begin{array}{l}\text { Hierarchy } \\
\text { Culture }\end{array}$ & $\begin{array}{l}\text { Market } \\
\text { Culture }\end{array}$ \\
\hline Job Satisfaction & 1 & $.225^{*}$ & $.253^{*}$ & $-.566^{*}$ & $-.563^{*}$ \\
\hline Clan Culture & $.225^{*}$ & 1 & & & \\
\hline $\begin{array}{l}\text { Adhocracy } \\
\text { Culture }\end{array}$ & $.253 *$ & $-.425 * *$ & 1 & & \\
\hline $\begin{array}{l}\text { Hierarchy } \\
\text { Culture }\end{array}$ & $-.556 * *$ & $-.274 * *$ & $-.285 * *$ & 1 & \\
\hline Market Culture & $-.563 * *$ & $-.312 * *$ & $-.357 * *$ & $.544 * *$ & 1 \\
\hline
\end{tabular}

$* \mathrm{p}<0.05, * * \mathrm{p}<0.01$

SIJMB | P-ISSN: 2313-1217 E-ISSN: 2410-1885 @ 201621 Sukkur Institute of Business Administration V.3, No.1 | Apr 16 
Table 2 depicts the correlation between the variables of study. It is evident from the results that a weak positive correlation of .225 exists between the variables of clan culture and job satisfaction. It signifies that when clan culture's attributes are more depicted in the values of the organization, job satisfaction of employees also increases. Similar is the case of adhocracy culture and job satisfaction which also weakly positive correlate with a correlation of .253. An increase in adhocracy cultural aspects will also increase the satisfaction of employees at work. The correlation between hierarchy culture and job satisfaction is moderate negative with a value of -.566 which indicates that an inverse relation exist between these two variables. An increase in hierarchy culture will decrease the job satisfaction. Similar is the result for market culture in which a moderate negative correlation -.563 exists between the variables of market culture and job satisfaction. An increase in market culture will result in decrease of job satisfaction.

\subsection{Regression Analysis}

Table 3: Regression Analysis

\begin{tabular}{llll}
\hline Variable & $\underline{\mathrm{B}}$ & $\underline{\mathrm{t}}$ & $\underline{\text { Significance }}$ \\
\hline (Constant) & 7.267 & 8.101 & .000 \\
Clan Culture & .225 & 2.510 & $.013 *$ \\
Adhocracy Culture & .426 & 4.663 & $.000 * * *$ \\
Hierarchy Culture & -.466 & -4.797 & $.000 * * *$ \\
Market Culture & -.356 & -4.020 & $.000 * * *$ \\
\hline p $<0.05, * * \mathrm{p}<0.01, * * * \mathrm{p}<0.001, \mathrm{R}^{2}=.414$ &
\end{tabular}

Regression analysis was performed to test the hypotheses of this study. Table 3 depicts the results which indicate that all the proposed hypotheses are being accepted. Employees working under clan culture are satisfied with their jobs as the hypothesis is accepted with a t value of 2.510 and the result is significant at $95 \%$ level of significance. The beta value of .225 which indicates that when 1 unit of clan culture increases it increase the job satisfaction by .225 units. Thus, $\mathrm{H} 1$ is accepted and null hypothesis is rejected. Adhocracy culture also positively impacts the job satisfaction as employees working under this type of culture are satisfied with their jobs, depicted by the results of regression. The $t$ value is 4.663 and the result is significant at all three level $90 \%$, $95 \%$ and $99 \%$. The beta value indicate that 1 unit increase in adhocracy culture will increase job satisfaction by .426 units, indicating that $\mathrm{H} 2$ is accepted and null hypothesis is rejected. Employees working under hierarchy culture are not satisfied with their job is depicted by the results with $t$ value of -4.797 which is significant at $90 \%, 95 \%$ and $99 \%$ level. The value of beta indicate that with an increase of 1 unit of hierarchy culture the job satisfaction decreases by -.446 indicating $\mathrm{H} 3$ is accepted and null hypothesis is rejected. Employees working under market culture are also dissatisfied with their jobs, shown by regression results. The t value is -4.020 and the results are significant at $90 \%$,

SIJMB | P-ISSN: 2313-1217 E-ISSN: 2410-1885 @ 201622 Sukkur Institute of Business Administration V.3, No.1 | Apr 16 
95\% and $99 \%$ with a beta value of -.356 . This indicates that with 1 unit increase of market culture the job satisfaction of employees will decrease by -.356 units, indicating $\mathrm{H} 4$ to be accepted and null hypothesis to be rejected.

For the value of $\mathrm{R}^{2}$ which is .414 shown below the table indicates that $41.4 \%$ change in job satisfaction of employees is caused by the independent variables of clan culture, adhocracy culture, hierarchy culture and market culture.

Regression Equation is given below:

Job satisfaction $=7.267+.225($ clan culture $)+.426($ adhocracy culture $)-.446$ (hierarchy culture) - .356 (market culture)

\section{Discussion and Conclusion}

The research was conducted in order to examine how organizational culture leads to the job satisfaction in entrepreneurial organizations. The study focused on the impact and influence of organizational culture types on job satisfaction of employees of various organizations. By identifying various types of organizational culture on the basis of literature, the model of Cameron and Quinn was utilized for this study. On the basis of the model the hypotheses of the study was established which suggested that clan and adhocracy culture are positively related to job satisfaction and hierarchy and market culture to be negatively associated with job satisfaction. The main aim of study was to fill out for the discrepancies found in the literature regarding the use of this particular model and to examine these variables in context of Asian culture which depict results in contrast to the Western studies.

The results produced from this study are consistent with the previous researches done in terms of the fact that organizational culture does have a significant relationship with the job satisfaction of employees Huey Yiing and Zaman Bin Ahmad (2009); McKinnon et al. (2003); Schiuma et al. (2012); Silverthorne (2004) particularly in the settings of entrepreneurial organizations. All four hypotheses were tested by using the organizational culture framework and the results produced suggests that as we move along the line employees working under clan and adhocracy show satisfaction with their jobs while those who work under hierarchy and market show dissatisfaction. Findings related to clan culture were similar to Schiuma et al. (2012) as employees feel safe and secure under a culture which is supportive, they tend to show satisfaction towards organization's environment from where they get the needed support Koberg and Chusmir (1987); Schiuma et al. (2012) found the relation of supportive culture with the job satisfaction of employees and their research results suggested the same as the result of this research that a positive association is there between clan culture and job satisfaction of employees. Kalliath and Morris (2002) evaluated that the level of job satisfaction has a direction relation with the structure of an organization. Flexible structures increase the job satisfaction of employees while inflexibility decreases the level of job satisfaction. The results regarding adhocracy culture were similar to that of McKinnon et al. (2003) as employees are more satisfied with their job in

SIJMB | P-ISSN: 2313-1217 E-ISSN: 2410-1885 @ 201623 Sukkur Institute of Business Administration V.3, No.1 | Apr 16 
organizations that opt for innovation and continuous improvements. The hierarchy culture results are also consistent with the research of Odom, Boxx, and Dunn (1990) as organizational culture has an impact on job satisfaction with the findings that bureaucratic culture leads to dissatisfaction of employees. Job satisfaction of employees is affected by the culture type in which the employees work and employees feel satisfied in culture where they get flexibility and are given autonomy rather than defined rules (Deshpande et al., (1993). Employees in medical care organizations are satisfied if given a culture which is not rigid and that do not contain fixed rules and regulation including commands for work (Nystrom, 1993).

K. Cameron and Quinn (1999) framework of organizational culture was utilized to conduct this study. The cultural model was used in relation to job satisfaction. All four cultures were evaluated with respect to their relation to job satisfaction. Following were the key results of this study:

1. Culture is a leading predictor of job satisfaction level of employees. According to the framework of K. Cameron and Quinn (1999) there are four types of organizational cultures. Employees who are working under the clan and adhocracy culture are found to be satisfied with their jobs, whereas results indicate that those who are working under the hierarchy and market culture were not satisfied with their jobs.

2. The variance is seen in the job satisfaction level of employees under different types of culture where they work. This variation is due to variability of characteristics and features of each culture type employees share.

3. The most popular and dominant type of culture is clan; clan is considered a culture with a welcoming environment. The second most popular culture type was adhocracy which is linked with higher job satisfaction as compared to other types from the model of organizational culture. Adhocracy is regarded as with a dynamic and creative place to work. Market culture and hierarchy culture were found to be in an inverse relationship with job satisfaction means scores. Market culture is defined as result-oriented, production intensive work place. Hierarchy culture is symbolized with informed procedures and methods that bind employees of the organization what to do, when to do, where to do and how to do.

\section{Limitations of the Study}

The limitations of study found were similar to that of Chang and Lee (2007). Due to time limitation factor the research investigations were limited to few factors.

\subsection{Geographical Limitations}

Although, this study explores a new dimension exploring organizational culture type relationships with job satisfaction however there are few limitations of study. Firstly, only organizations of geographical location of Rawalpindi and Islamabad were used to gather data. The total numbers of organizations studied under this research were eleven

SIJMB | P-ISSN: 2313-1217 E-ISSN: 2410-1885 @ 201624 Sukkur Institute of Business Administration V.3, No.1 | Apr 16 
in number. So the findings can never be generalized for organizations outside this geographical location which is one of the main constraints of this research. Due to this constraint external validity of this study is quite low. However, result of another study conducted on marketing professionals of USA showed similar results as of this study. Even though, USA is quite different from Pakistan in context of politics, economy and culture, but results of that study supports findings of this study and enhance its validity to a certain extent.

\subsection{Sampling Limitations}

Convenient sampling was used to collect data from employees of eleven organizations of Rawalpindi and Islamabad. Due to this factor the biasness of the study increased and generalizability of study is reduced. This study can be analyzed in more detail, but due to time constraint many other dimensions are not touched.

\subsection{Study Design Limitations}

Design of this study was cross-sectional i.e. one point data is collected, this reduced relationship of model presented in this study. In order to make study more robust and strong in nature longitudinal study is the appropriate study which does take time but provides long lasting results which have a bigger impact.

\section{Implications and Future Research Directions}

To overcome limitations of this study, few future research directions are provided to explore this model more accurately. This study was about relationship of organizational culture type on job satisfaction of employees of organizations of Islamabad and Rawalpindi but the organizations accessed were much smaller in size. Telecom sector and banking sector was not targeted at all. The organizations targeted exhibit very specific form of organizational structure and its culture is always different from other organizations of Pakistan. In order to increase external validity and be at more generalized findings, this study need to be conducted in diverse geographical and occupational settings. In future, the same model should be tested in different organizational sectors e.g. telecom sector, textile sector, banking industry and in government organizations as well.

Coming towards next limitation, in future longitudinal study needs to be conducted. So, respondents' biasness will be minimized when questions of independent and dependent variables will be asked at different times. This will enhance robustness of study. Along with this, in future, probability sampling could be used to make this study more generalized.

Though, the study contains certain limitations but it does provide significant implications for managers. As the results suggests that the type of culture that prevails in an organization impacts the job satisfaction of employees, the sub factors of culture must be in coherence with each other. For example, if the organization is a supportive place, the leader must also be facilitator, the work environment must be team based,

SIJMB | P-ISSN: 2313-1217 E-ISSN: 2410-1885 @ 201625 Sukkur Institute of Business Administration V.3, No.1 | Apr 16 
there must be trust among the members of the organizations and in order to build commitment employee participation must also be the essential part. Also, organizations must focus on the development of its employees and they must keep employees ahead of everything by keeping them as the priority. The study also helped in identifying that culture type is a significant aspect which must not be ignored at all. Employees who work under conditions where they are not given voice in form of participation, the leadership is self-focused, the strategic direction uses employees just as a mean and there is no human development leads to dissatisfaction of employees which can cause consequences for the organizations.

In conclusion it is critical to note that the type of organizational culture has a substantial impact on the satisfaction of employees and the sub cultural factors must be keenly seen by the managers so that their employees stay satisfied.

\section{References}

Adler, N. J., \& Jelinek, M. (1986). Is "organization culture" culture bound? Human Resource Management, 25(1), 73-90.

Agho, A. O., Mueller, C. W., \& Price, J. L. (1993). Determinants of employee job satisfaction: An empirical test of a causal model. Human relations, 46(8), 10071027.

Boxx, W. R., Odom, R. Y., \& Dunn, M. G. (1991). Organizational values and value congruency and their impact on satisfaction, commitment, and cohesion: An empirical examination within the public sector. Public Personnel Management, 20(2), 195-205.

Brooke, P. P., Russell, D. W., \& Price, J. L. (1988). Discriminant validation of measures of job satisfaction, job involvement, and organizational commitment. Journal of applied psychology, 73(2), 139.

Buono, A. F., Bowditch, J. L., \& Lewis, J. W. (1985). When cultures collide: The anatomy of a merger. Human relations, 38(5), 477-500.

Cameron, K., \& Quinn, R. (1999). Diagnosing and changing organisational behaviour: Based on the competing values framework. Massachusetts: Addison-Wesley.

Cameron, S. K., \& Freeman, J. S. (1991). Cultural congruence, strength, and type: relationships to effectiveness. Research in Organizational Change and Development, 5, 23-58.

Chan, L. L., Shaffer, M. A., \& Snape, E. (2004). In search of sustained competitive advantage: the impact of organizational culture, competitive strategy and human resource management practices on firm performance. The International Journal of Human Resource Management, 15(1), 17-35.

Chang, S.-C., \& Lee, M.-S. (2007). A study on relationship among leadership, organizational culture, the operation of learning organization and employees' job satisfaction. The Learning Organization, 14(2), 155-185.

Chatman, J. A. (1989). Improving interactional organizational research: A model of person-organization fit. Academy of management Review, 14(3), 333-349.

SIJMB | P-ISSN: 2313-1217 E-ISSN: 2410-1885 @ 201626 Sukkur Institute of Business Administration V.3, No.1 | Apr 16 
Chatman, J. A., Polzer, J. T., Barsade, S. G., \& Neale, M. A. (1998). Being different yet feeling similar: The influence of demographic composition and organizational culture on work processes and outcomes. Administrative Science Quarterly, 749-780.

Chen, W. (2002). The relationship research among organizational culture, leadership behaviors and organizational commitment-take local banks in Chiayi and Tainan areas for example. unpublished MS thesis, National Cheng Kung University, Taiwan.

Daft, R. (2001). Organization theory and design (7. international student edition Aufl.). Mason: Thomson/South-Western.

Davis, S. M. (1990). Managing corporate culture: Ballinger Pub Co.

Deal, T. E., \& Kennedy, A. A. (1982). Corporate cultures: The rites and rituals of organizational life. Reading/T. Deal, A. Kennedy.-Mass: Addison-Wesley, 2, 98-103.

Deshpande, R., Farley, J. U., \& Webster Jr, F. E. (1993). Corporate culture, customer orientation, and innovativeness in Japanese firms: a quadrad analysis. The journal of Marketing, 23-37.

Deshpande, R., \& Parasuraman, A. (1986). Linking corporate culture to strategic planning. Business Horizons, 29(3), 28-37.

Flynn, F. J., Chatman, J. A., \& Spataro, S. E. (2001). Getting to know you: The influence of personality on impressions and performance of demographically different people in organizations. Administrative Science Quarterly, 46(3), 414442.

Hansen, G. S., \& Wernerfelt, B. (1989). Determinants of firm performance: The relative importance of economic and organizational factors. Strategic management journal, 10(5), 399-411.

Hofstede, G. (1984). Culture's consequences: International differences in work-related values (Vol. 5): sage.

Hofstede, G., Neuijen, B., Ohayv, D. D., \& Sanders, G. (1990). Measuring organizational cultures: A qualitative and quantitative study across twenty cases. Administrative Science Quarterly, 286-316.

Huang, I., \& Wu, J. (2000). The corporate culture and its effect on organizational commitment and job satisfaction in public sector: An example of the Taiwan Tobacco and Liquor Monopoly Bureau. Review of Public-owned Enterprises, 2(1), 25-46.

Huey Yiing, L., \& Zaman Bin Ahmad, K. (2009). The moderating effects of organizational culture on the relationships between leadership behaviour and organizational commitment and between organizational commitment and job satisfaction and performance. Leadership \& Organization Development Journal, 30(1), 53-86.

J. JOHNSON, J., \& McIntye, C. L. (1998). Organizational culture and climate correlates of job satisfaction. Psychological Reports, 82(3), 843-850.

Kalliath, T., \& Morris, R. (2002). Job satisfaction among nurses: a predictor of burnout levels. Journal of Nursing Administration, 32(12), 648-654.

SIJMB | P-ISSN: 2313-1217 E-ISSN: 2410-1885 @ 201627 Sukkur Institute of Business Administration V.3, No.1 | Apr 16 
Kangas, S., Kee, C. C., \& McKee-Waddle, R. (1999). Organizational factors, nurses' job satisfaction, and patient satisfaction with nursing care. Journal of Nursing Administration, 29(1), 32-42.

Koberg, C. S., \& Chusmir, L. H. (1987). Organizational culture relationships with creativity and other job-related variables. Journal of Business research, 15(5), 397-409.

Locke, E. A. (1969). What is job satisfaction? Organizational behavior and human performance, 4(4), 309-336.

Locke, E. A. (1970). Job satisfaction and job performance: A theoretical analysis. Organizational behavior and human performance, 5(5), 484-500.

Lok, P., \& Crawford, J. (1999). The relationship between commitment and organizational culture, subculture, leadership style and job satisfaction in organizational change and development. Leadership \& Organization Development Journal, 20(7), 365-374.

Lund, D. B. (2003). Organizational culture and job satisfaction. Journal of business \& industrial marketing, 18(3), 219-236.

MacIntosh, E., \& Doherty, A. (2005). Leader intentions and employee perceptions of organizational culture in a private fitness corporation. European Sport Management Quartely, 5(1), 1-22.

MacIntosh, E., \& Doherty, A. (2007). Extending the scope of organisational culture: The external perception of an internal phenomenon. Sport Management Review, 10(1), 45-64.

MacIntosh, E., \& Doherty, A. (2008). Inside the Canadian Fitness Industry: Development Of a Conceptual Framework of Organizational Structure. International Journal of Sport Management, 9(3), 303.

Martin, J. (1992). Cultures in organizations: Three perspectives: Oxford University Press.

McKinnon, J. L., Harrison, G. L., Chow, C. W., \& Wu, A. (2003). Organizational culture: Association with commitment, job satisfaction, propensity to remain, and information sharing in Taiwan. International Journal of Business Studies, 11(1), 25.

Nystrom, P. C. (1993). Organizational cultures, strategies, and commitments in health care organizations. Health Care Management Review, 18(1), 43-49.

O'Reilly, C. A., Chatman, J., \& Caldwell, D. F. (1991). People and organizational culture: A profile comparison approach to assessing person-organization fit. Academy of management journal, 34(3), 487-516.

Odom, R. Y., Boxx, W. R., \& Dunn, M. G. (1990). Organizational cultures, commitment, satisfaction, and cohesion. Public Productivity \&amp; Management Review, 157-169.

Quinn, R. E. (1988). Beyond rational management: Mastering the paradoxes and competing demands of high performance: Jossey-Bass.

Quinn, R. E., \& McGrath, M. R. (1985). The transformation of organizational cultures: A competing values perspective. Organizational culture, 315-334.

SIJMB | P-ISSN: 2313-1217 E-ISSN: 2410-1885 @ 201628 Sukkur Institute of Business Administration V.3, No.1 | Apr 16 
Quinn, R. E., \& Rohrbaugh, J. (1983). A spatial model of effectiveness criteria: Towards a competing values approach to organizational analysis. Management science, 29(3), 363-377.

Robinson, D., Porporino, F. J., \& Simourd, L. (1996). Do different occupational groups vary on attitudes and work adjustment in corrections. Fed. Probation, 60, 45.

Rosenfield, R. H., \& Wilson, D. (1998). Managing Organizations: McGrawHill.

Schein, E. H. (1984). Coming to a new awareness of organizational culture. Sloan management review, 25(2), 3.

Schein, E. H. (1990). Organizational culture (Vol. 45): American Psychological Association.

Schein, E. H. (1996). Culture: The missing concept in organization studies. Administrative Science Quarterly, 229-240.

Schiuma, G., Carlucci, D., Lerro, A., Bigliardi, B., Ivo Dormio, A., Galati, F., \& Schiuma, G. (2012). The impact of organizational culture on the job satisfaction of knowledge workers. Vine, 42(1), 36-51.

Schneider, B., \& Snyder, R. A. (1975). Some relationships between job satisfaction and organization climate. Journal of applied psychology, 60(3), 318.

Shurbagi, A. M., \& Zahari, I. (2012). The Relationship between Organizational Culture and Job Satisfaction in National Oil corporation of Libya. International Journal of Humanities and Applied sciences, 83-93.

Silverthorne, C. (2004). The impact of organizational culture and person-organization fit on organizational commitment and job satisfaction in Taiwan. Leadership \& Organization Development Journal, 25(7), 592-599.

Spector, P. E. (1997). Job satisfaction: Application, assessment, causes, and consequences (Vol. 3): Sage publications.

Wallach, E. J. (1983). Individuals and organizations: The cultural match. Training \& Development Journal.

Wilkins, A. L. (1983). The culture audit: A tool for understanding organizations. Organizational dynamics, 12(2), 24-38.

Williams, E. S., Manwell, L. B., Konrad, T. R., \& Linzer, M. (2007). The relationship of organizational culture, stress, satisfaction, and burnout with physicianreported error and suboptimal patient care: results from the MEMO study. Health Care Management Review, 32(3), 203-212.

Wright, T. A., \& Cropanzano, R. (1998). Emotional exhaustion as a predictor of job performance and voluntary turnover. Journal of applied psychology, 83(3), 486.

SIJMB | P-ISSN: 2313-1217 E-ISSN: 2410-1885 @ 201629 Sukkur Institute of Business Administration V.3, No.1 | Apr 16 


\section{APPENDIX (A)}

\section{Questionnaire:}

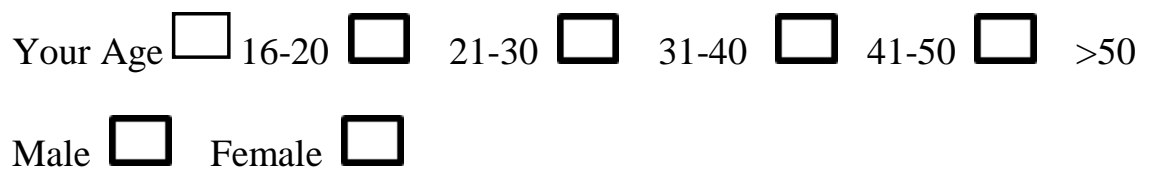

For how long you have been working for the organization: less than a year $\square$ 1-5 years $\square$ 6-10 years $\square$ more than 10 years $\square$

The following statements describe the statements regarding the organization you are working for. For each, please indicate the extent to which you agree/disagree with the statements by mentioning the appropriate number on the scale.

Strongly Disagree

12
3

\section{DOMINANT CHARACTERISTICS}

a. The organization is a very special place. It is like an extended family. People seem to share a lot of themselves.

b. The organization is a very dynamic and entrepreneurial place. People are willing to stick their necks out and take risks.

c. The organization is very production oriented. A major concern is with getting the job done. People are very competitive and achievement oriented.

d. The organization is a very formalized and structured place. Bureaucratic procedures generally govern what people do.

\section{ORGANIZATIONAL LEADERS}

a. The leaders of the organization are generally considered to be mentors, facilitators, or parent figures.

b. The leaders of the organization are generally considered to be entrepreneurs, innovators, or risk takers.

c. The leaders of the organization are generally considered to be harddrivers, producers, or competitors.

d. The leaders of the organization are generally considered to be coordinators, organizers, or efficiency experts.

\section{MANAGEMENT OF EMPLOYEES}

a. The management style in the organization is characterized by teamwork, consensus and participation. 
b. The management style in the organization is characterized by individual risk-taking, innovation, flexibility, and uniqueness.

c. The management style in the organization is characterized by harddriving competitiveness, goal directedness, and achievement.

d. The management style in the organization is characterized by careful monitoring of performance, longevity in position, and predictability.

\section{ORGANIZATION GLUE}

a. The glue that holds the organization together is loyalty and mutual trust. Commitment to this organization runs high.

b. The glue that holds the organization together is orientation toward innovation and development. There is an emphasis on being on the cutting edge.

c. The glue that holds the organization together is the emphasis on production and goal accomplishment. Marketplace aggressiveness is a common theme.

d. The glue that holds the organization together is formal rules and policies. Maintaining a smooth running organization is important.

\section{STRATEGIC EMPHASES}

a. The organization emphasizes human development. High trust, openness and participation persist.

b. The organization emphasizes acquiring new resources and meeting new challenges. Trying new things and prospecting for new opportunities are valued.

c. The organization emphasizes competitive actions and achievement. Measurement targets and objectives are dominant.

d. The organization emphasizes permanence and stability. Efficient, smooth operations are important.

\section{CRITERIA OF SUCCESS}

a. The organization defines success on the basis of development of human resources, teamwork, and concern for people.

b. The organization defines success on the basis of having the most unique or the newest products. It is a product leader and innovator.

c. The organization defines success on the basis of market penetration and market share. Competitive market leadership is key.

d. The organization defines success on the basis of efficiency. Dependable delivery, smooth scheduling, and low cost production are critical.

The following statements describe your feelings towards certain job-related issues regarding the organization you currently work for. For each, please indicate the extent

SIJMB | P-ISSN: 2313-1217 E-ISSN: 2410-1885 @ 201631 Sukkur Institute of Business Administration V.3, No.1 | Apr 16 
to which you agree/disagree with the statements by mentioning the appropriate number on the scale.

\section{Strongly Disagree}

1 2

3

Strongly Agree

A. All in all, I am satisfied with the work of my job.

B. All in all, I am satisfied with my co-workers.

C. All in all, I am satisfied with the supervision.

D. All in all, I am satisfied with my pay (total wages and other benefits).

All in all, I am satisfied with the promotional opportunities.

SIJMB | P-ISSN: 2313-1217 E-ISSN: 2410-1885 @ 201632 Sukkur Institute of Business Administration V.3, No.1 | Apr 16 